\title{
Review \\ Colletotrichum Species Complexes Associated with Crops in Northern South America: A Review
}

\author{
Marcela Guevara-Suarez ${ }^{1,2}$, Martha Cárdenas ${ }^{2}$ (D) Pedro Jiménez ${ }^{3}$, Lucía Afanador-Kafuri ${ }^{4}$ \\ and Silvia Restrepo $2, *$ (D)
}

1 Applied Genomics Research Group, Vice-Presidency for Research and Creation, Universidad de los Andes, Bogotá 111711, Colombia; mi.guevara34@uniandes.edu.co

2 Laboratorio de Micología y Fitopatología (LAMFU), Facultad de Ingeniería, Universidad de los Andes, Bogotá 111711, Colombia; martcard@uniandes.edu.co

3 Facultad de Ciencias Básicas y Aplicadas, Universidad Militar Nueva Granada, Cajicá 250247, Colombia; pedro.jimenez@unimilitar.edu.co

$4 \quad$ Facultad de Ciencias Agrarias, Universidad Nacional de Colombia, Medellín 050034, Colombia; lafanado@unal.edu.co

* Correspondence: srestrep@uniandes.edu.co; Tel.: +57-1-3394949

Citation: Guevara-Suarez, M.; Cárdenas, M.; Jiménez, P.; Afanador-Kafuri, L.; Restrepo, S. Colletotrichum Species Complexes Associated with Crops in Northern South America: A Review. Agronomy 2022, 12, 548. https://doi.org/ 10.3390/agronomy12030548

Academic Editor: Gavin Ash

Received: 31 December 2021

Accepted: 14 February 2022

Published: 23 February 2022

Publisher's Note: MDPI stays neutral with regard to jurisdictional claims in published maps and institutional affiliations.

Copyright: (C) 2022 by the authors. Licensee MDPI, Basel, Switzerland. This article is an open access article distributed under the terms and conditions of the Creative Commons Attribution (CC BY) license (https:// creativecommons.org/licenses/by/ $4.0 /)$.

\begin{abstract}
Colletotrichum genus comprises a high number of plant pathogens causing anthracnose disease in different tropical and non-tropical crops. We aimed to review northern South American studies in the online SCOPUS database to: create a taxonomically updated list of the species complexes found in the region, describe their most important phytopathological characteristics, revise the methods used in the region to control disease, and discuss the role of fungus as a plant endophyte. A total of 19 Colletotrichum species within five complexes-acutatum, boninense, gigasporum, gloeosporioides, and orbiculare-have been reported in northern South America. Few studies have been conducted, particularly in Peru and Ecuador, despite the diversity of Colletotrichum hosts cultivated in the region. Important information can be extracted from our review: species do not appear to show host specificity, although some isolates show host preferences, certain plant species can host several Colletotrichum species, some studies show the importance of using plant extracts to control the disease, but biological control using microorganisms is certainly an open area of research in the region. In northern South America, only a few hosts have been reported to harbor Colletotrichum as endophyte, and the potential of these endophytes as biological control agents has not yet been explored.
\end{abstract}

Keywords: anthracnose; endophyte; species complexes

\section{Introduction}

The genus Colletotrichum (Sordariomycetes, Ascomycota) includes an important number of plant pathogens for vegetables, legumes, cereals, and tropical and non-tropical crops worldwide [1,2]. Many Colletotrichum species have been named after their hosts. Taxonomically, Colletotrichum is a confusing genus that has been subject to various taxonomic revisions in the last few years [3-5]. Additionally, numerous species have been described since its first report in 1831 by Corda [6]. According to the Index Fungorum Database, there are a total of 942 records for Colletotrichum. However, recent taxonomic studies and the EPPO-Q-BANK database suggest that there are currently only about 257 accepted species. Colletotrichum species are distributed across 15 major monophyletic clades or species complexes: acutatum, agaves, boninense, caudatum, dematium, destructivum, dracaenophilum, gigasporum, gloeosporioides, graminicola, magnum, orbiculare, orchidearum, spaethianum and truncatum $[7,8]$.

The taxonomy of Colletotrichum has recently changed based on available molecular data and subsequent phylogenetic analyses since phenotypic features alone are not informative. In the last decade, species within this genus have been delineated based on a 
polyphasic approach that has mainly involved evaluation of morphological characters and multi-locus sequence analyses of molecular markers such as internal transcribed spacer region rDNA (ITS), $\beta$-tubulin (TUB), actin (ACT), calmodulin (CAL), chitin synthase I (CHS-1), glyceraldehyde-3-phosphate dehydrogenase (GAPDH), the large subunit of RNA polymerase II (RPB2), and translation elongation factor 1- $\alpha(\mathrm{EF} 1 \alpha)$. Although the ITS region alone cannot identify or differentiate species in the genus, it can be used to separate taxa at the species complex level. In addition, some genes like GAPDH can be useful to preliminarily perform an identification to the species level $[9,10]$.

In the northern South American region (Colombia, Ecuador, Peru, and Venezuela) many tropical crops have been affected by Colletotrichum species $[5,8]$. Therefore, in each country there is an interest to characterize the pathogen and most studies are focused on its isolation, morphological identification and phytopathological behavior. However, to date there are no papers that integrate this information at the regional level.

Consequently, this review has four goals: (i) to list the species complexes and, when available, the species of Colletotrichum associated with cultivated hosts in Colombia, Ecuador, Peru, and Venezuela; (ii) to review the geographical range of the pathogen in the northern region of South America, as reported in the literature; (iii) to describe their most important phytopathological characteristics: hosts, specificity, and methods of control; and (iv) to review the role of fungi belonging to the genus Colletotrichum as endophytes.

\section{Materials and Methods}

We reviewed the studies that included isolates of Colletotrichum genus associated with cultivated plants in the northern region of South America, which includes Colombia, Ecuador, Peru, and Venezuela. This search was performed in the online SCOPUS database using the keyword phrases "Colletotrichum AND Colombia," "Colletotrichum AND Peru," "Colletotrichum AND Ecuador," and "Colletotrichum AND Venezuela". We included papers in English and Spanish published in peer-reviewed research journals.

In addition, in order to list the Colletotrichum species complexes associated with cultivated hosts in Colombia, Ecuador, Peru, and Venezuela we performed a phylogenetic analysis of available sequences retrieved from GenBank that were reported in the studies included in this review. We also included sequences of the type strains of most of the accepted species in the genus. To ensure that we included most of the isolates reported in the studied region, we could only be able to include the molecular marker used in most of the studies reviewed: the ITS region comprising the 5.8S nuclear ribosomal gene. The sequences were aligned using the MAFFT algorithm in the EMBL-EBI Web Services portal and manually adjusted using MEGA v 6.0 [11]. Phylogenetic reconstructions by maximum likelihood (ML) and Bayesian inference (BI) were carried out using MEGA v. 6.0 and MrBayes v. 3.1.2 [12]. For ML, the trees were inferred using the heuristic method Nearest-Neighbor-Interchange, and gaps underwent partial deletion with a 95\% site coverage cut-off. Phylogeny support for internal branches was assessed by $1000 \mathrm{ML}$ bootstrapped pseudo-replicates, and the bootstrap support (bs $\geq 70$ ) was considered significant. The BI analyses were performed using one million Markov chain Monte Carlo (MCMC) generations, with two runs (one cold and three heated chains) and samples were stored every 1000 generations. The 50\% majority-rule consensus tree and posterior probability values (pp) were calculated after discarding the first $25 \%$ of the samples. A pp value $\geq 0.95$ was considered significant. The best substitution models for each data partition were estimated using the jModelTest v.2.1.3 based on the Akaike criterion [13,14]. The resulting trees were plotted using FigTree v.1.3.1 and edited in Adobe Illustrator CS3.

\section{Results and Discussion}

A total of 105 research articles on Colletotrichum in northern South America (Ecuador, Venezuela, Peru, and Colombia), were obtained in November 2021. We excluded the articles that focused on host resistance, or reviews of other fungi, and we retained 71 articles (Table S1). Next, we will present the most relevant aspects of our review. 


\subsection{Species Complexes of Colletotrichum Associated with Crops in Northern South America}

We obtained a total of 192 sequences for the ITS region. The aligned dataset was $465 \mathrm{bp}$ long, with 158 variable sites and 114 phylogenetic informative sites. The best substitution model for ML was determined to be T92+G. In general, the topology of the phylogenetic tree showed well-delimitated clades. This analysis showed that the species reported in Colombia, Ecuador, Peru, and Venezuela are mainly distributed across five clades of Colletotrichum (acutatum, boninense, gigasporum, gloeosporioides, and orbiculare), with most of the species observed in the gloeosporioides clade (Figure 1).

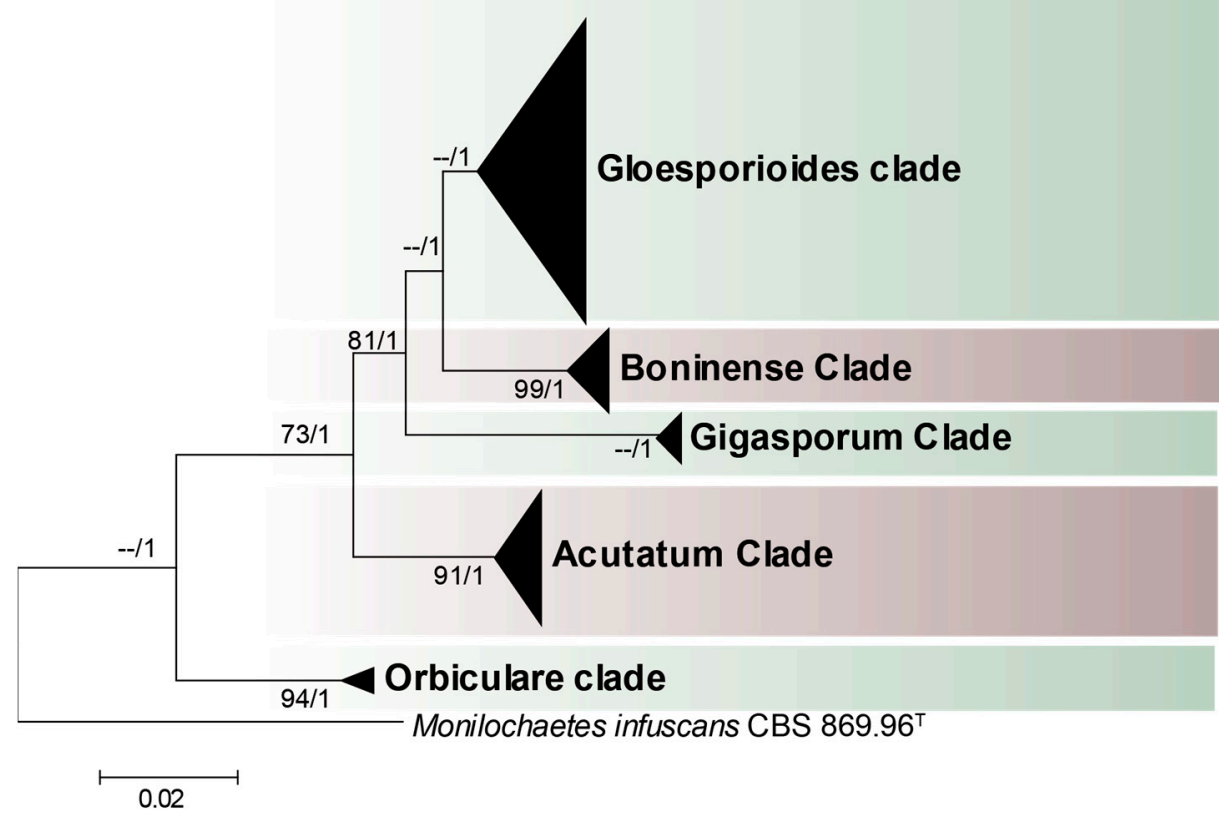

Figure 1. An ML tree of the Colletotrichum clades reported in northern South America (Colombia, Ecuador, Peru, and Venezuela). The tree was created based on the alignment of ITS sequences (465 bp) retrieved from GenBank. Branch lengths are proportional to phylogenetic distance. The best substitution model for ML was determined to be T92+G. Bootstrap support values/Bayesian posterior probability scores above $70 \% / 0.95$ are indicated on the nodes. The tree was rooted to Monilochaetes infuscans CBS 869.96 (type strain).

The first clade corresponds to species in the C. gloeosporioides complex. Currently, this group comprises 57 species, which are mainly characterized as phytopathogens and sometimes reported to be endophytes [8-10]. Most isolates reported for northern South America are clustered in this complex (Figure 2). Although the ITS region is not a good molecular marker for identifying closely related species, we were able to identify seven species in this complex: C. asianum, C. fructicola, C. cigarro (formerly C. kahawae subsp. ciggaro), C. gloesporioides sensu stricto, C. musae, C. siamense, and C. theobromicola. A small number of isolates were located in a closely related group containing species with identical ITS sequences (C. aenigma, C. cobbittiense, $C$. changpingense, C. tropicale, and C. yulongense). For these species, a multi-locus analysis including the ApMat-Intergenic region of apn 2 and MAT1-2-1 genes, which has been proposed to differentiate at the species level within the $C$. gloeosporioides complex, is necessary [15]. Our analyses suggested that some isolates $(n=15)$ in this group that are likely mislabeled and need to be revised. On the other hand, we found one ITS sequence deposited in GenBank as C. rhexiae (accession number KJ846800), this sequence was obtained from tree tomato in Colombia, but according to our analyses (Figure 2) and a literature review, this sequence could be mislabeled. To date, C. rhexiae has only been isolates from leaf and stem of Rhexia virginica and from fruits of Vaccinium 
macrocarpon [8,16]. One of the most reported species was C. kahawae subsp. ciggaro. Recently, the taxonomic status of C. kahawae subsp. ciggaro was updated and it is now considered a species which was named as C. cigarro [17]. All isolates of our search were clustered within C. cigarro. This last determination is important because C. kahawae is a significant pathogen of Coffea arabica, a crop with agricultural importance in the region.

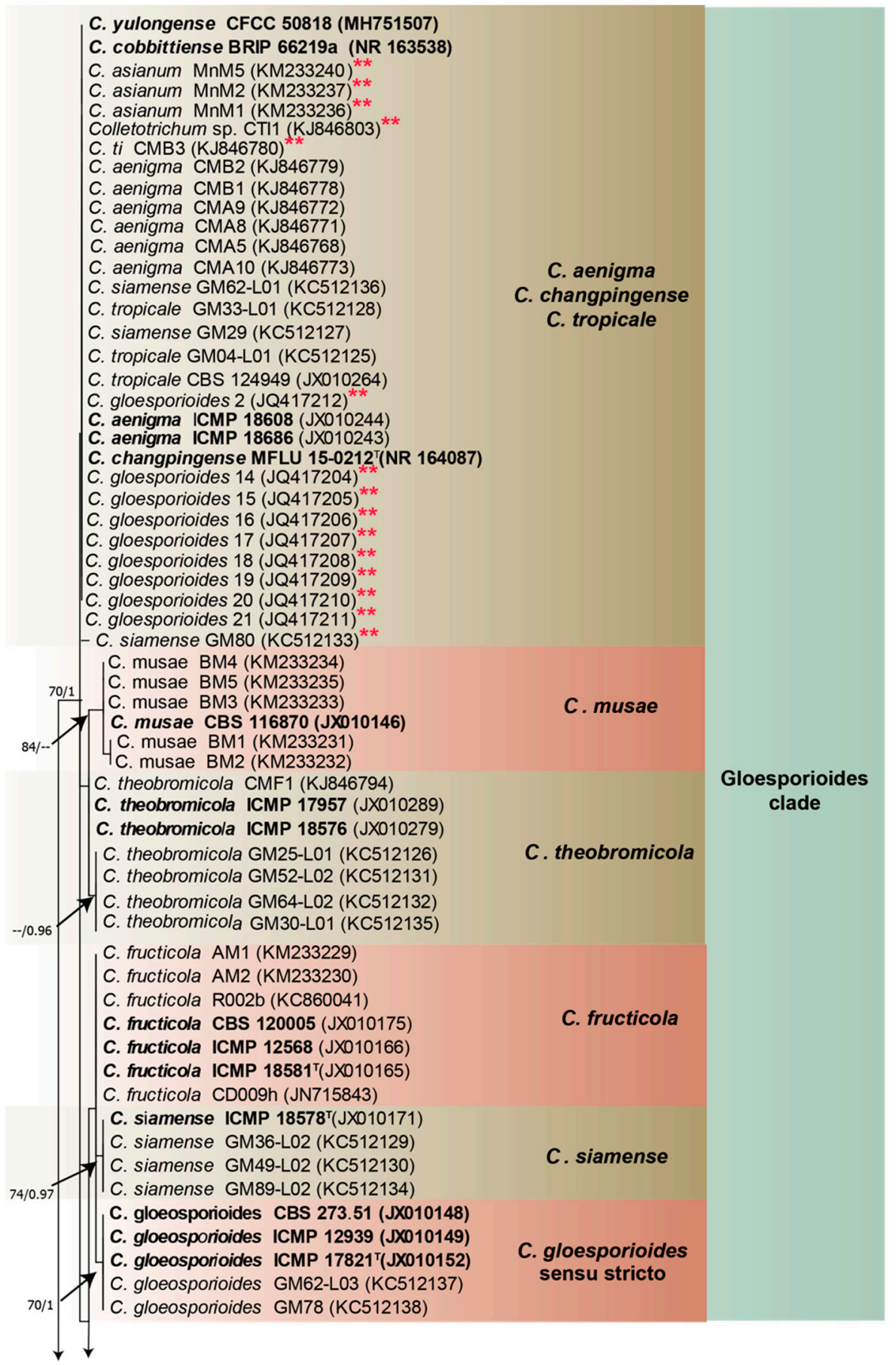

Figure 2. Cont. 


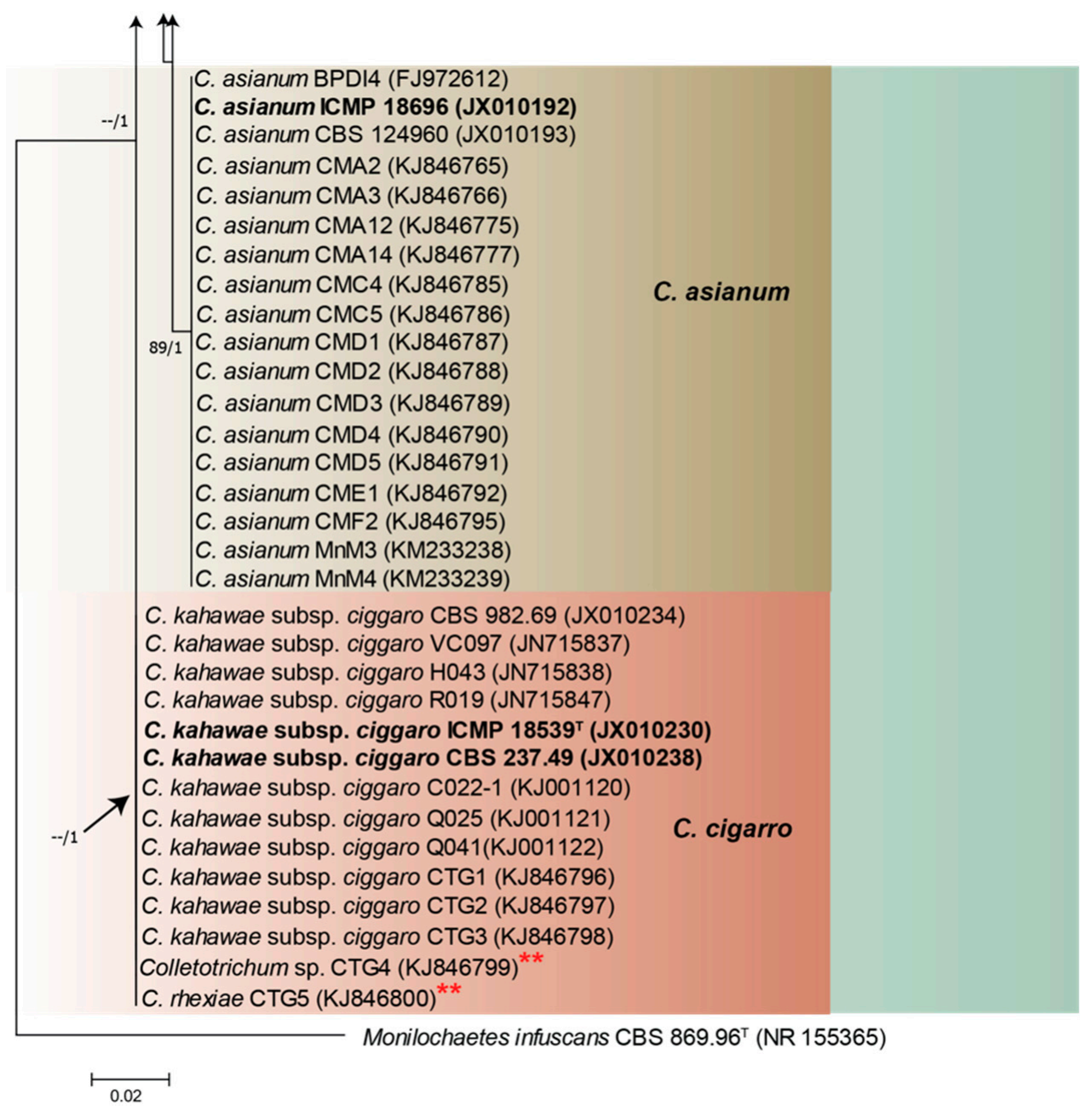

Figure 2. An ML tree of the gloesporioides clade that includes species reported in northern South America (Colombia, Ecuador, Peru, and Venezuela). The tree was created based on the alignment of ITS (434 bp). The GenBank accession numbers of sequences retrieved from the database are given in parentheses. Reference strains are shown in bold. Branch lengths are proportional to phylogenetic distance. The best substitution model for ML was determined to be T92+G. Bootstrap support values/Bayesian posterior probability scores above 70\%/0.95 are indicated on the nodes. The tree was rooted to Monilochaetes infuscans CBS 869.96. ${ }^{\mathrm{T}}=$ Ex-type strain. ${ }^{* *}$ Isolates are probably mislabeled in GenBank.

Moreno-Moran and Burbano-Figueroa (2016) reported C. gossypii in cotton ramulosis in Colombia [18]. However, the isolates presented in this study could not be included in our analysis because there are no available ITS sequences. Moreno-Moran and BurbanoFigueroa [18] used TUB and GAPDH sequences to identify isolates, but Weir et al. [9] reported that there are no sequences available for these genes for the ex-type strain, and therefore accurate molecular identification of this species is not possible.

The boninense clade (Figure 3) is one of the largest complexes within the Colletotrichum genus. Species within this complex are considered to be pathogens and endophytes $[19,20]$. The isolates from northern South America included in our analysis were distributed into four subclades. The first includes C. boninense, C. brassicicola, and C. colombiense, which cannot be identified with certainty using ITS sequences because the sequences of ex-type strains are identical. Colletotrichum colombiense was described by Damm et al. [20] from a leaf of Passiflora edulis in the department of Cundinamarca, Colombia. The authors highlighted that Afanador-Kafuri et al. [21] isolated many other isolates of Colletotrichum from the same host; however, these isolates could not be assigned to the $C$. colombiense species due 
to the fact that only their ITS sequences were available. The second subclade includes Colletotrichum sp. GM52-L01 [22]. We reviewed all available sequences of this isolate (data not shown), but we could not perform identification at the species level since no ex-type strain was included in this group, and a BLASTn search (non-redundant (nr) database and default parameters) revealed a low percentage of similarity. The third subclade includes the only species that could be identified, C. karstii. The fourth subclade includes Colletotrichum sp. Q026 [23], which is closely phylogenetically related to C. pryrifolia, a species that was recently described in association with the Pyrus species in China. However, according to the description of this species, C. pryrifolia differs from Colletotrichum sp. Q026 in the size of the conidia and in the ACT and TUB2 sequences. Interestingly, Colletotrichum sp. Q026 and Colletotrichum sp. GM52-L01 could be two new species within the boninense clade.

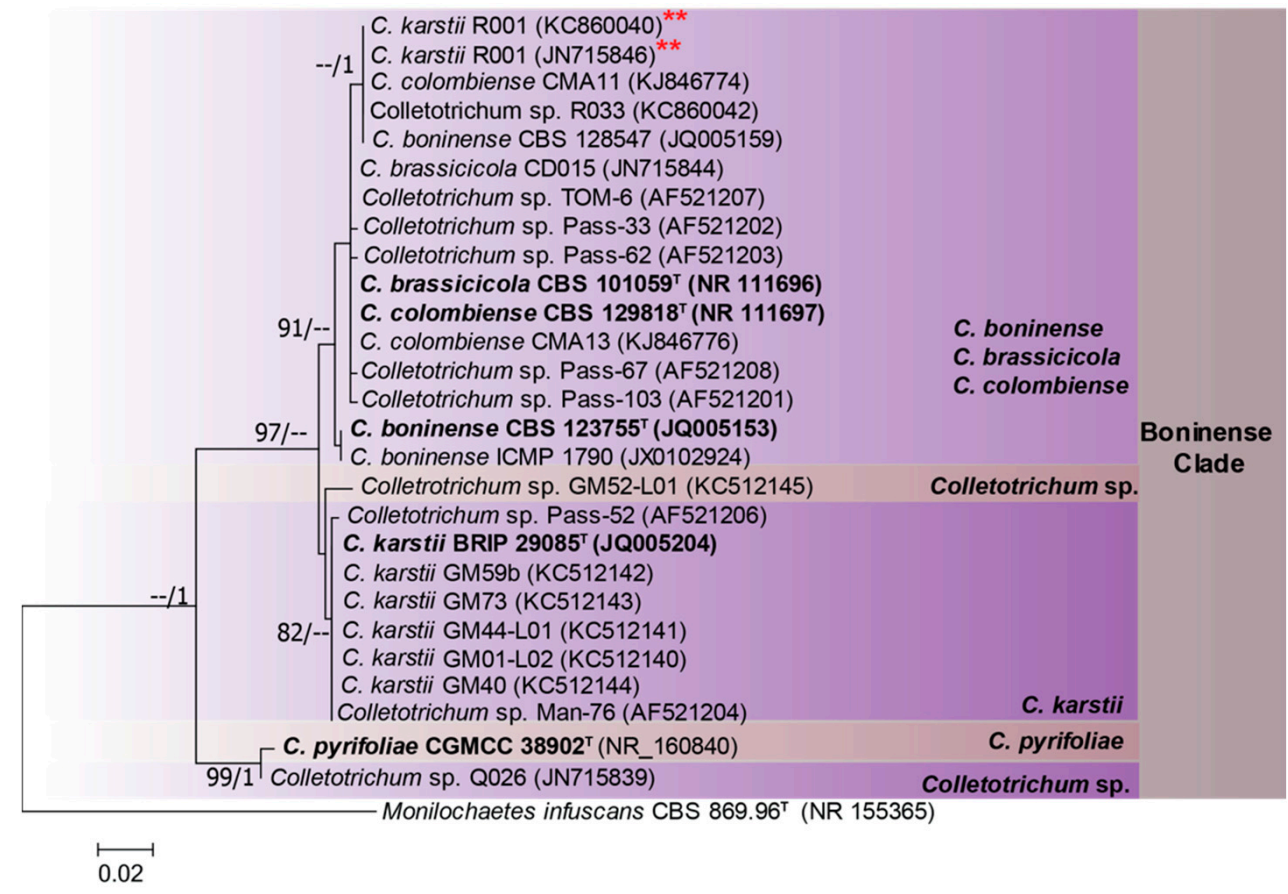

Figure 3. An ML tree of the boninense clade that includes species reported in northern South America (Colombia, Ecuador, Peru, and Venezuela). The tree was created based on the alignment of ITS (449 bp). The GenBank accession numbers of sequences retrieved from the database are given in parentheses. Reference strains are shown in bold. Branch lengths are proportional to phylogenetic distance. The best substitution model for ML was determined to be T92+G. Bootstrap support values/Bayesian posterior probability scores above $70 \% / 0.95$ are indicated on the nodes. The tree was rooted to Monilochaetes infuscans CBS 869.96. ${ }^{\mathrm{T}}=$ Ex-type strain. ${ }^{* *}$ Isolates are probably mislabeled in GenBank.

In the orbiculare and gigasporum clades, only one species was identified in each complex: C. lindemuthianum and C. gigasporum, respectively (Figure 4). Colletotrichum lindemuthianum is one of eight species in the orbiculare clade, and it is restricted to Phaseolus vulgaris and P. coccineus (Fabaceae) [24]. A total of five isolates obtained from P. vulgaris in Colombia were included in our analysis and formed a different clade than those already reported for C. lindemuthianum [24]. The C. gigasporum species complex includes eight species. Among these, C. gigasporum is the most frequently isolated species, and it seems to have a wide host range and geographic distribution. Colletotrichum gigasporum was described by Rakotoniriana et al. [25], including one isolate from Colombia (VEGA 508, FN557349) obtained as an endophytic fungus from Coffea arabica. To our knowledge this would be the first and only report of $C$. gigasporum in the region. 
Finally, in the acutatum clade, we identified two species-C. godetiae and C. tamarilloithe latter of which is the most reported species in the region (Figure 5). Members of the acutatum clade have been reported in agricultural and natural hosts across the world. This species complex includes approximately 41 species, of which C. acutatum and closely related species are considered pathogens that cause rot in fruit trees [20]. In addition, the complex includes one of the most important pathogens in the region, C. tamarilloi, which is the causal agent of anthracnose in Solanum betaceum (tree tomato, tamarillo), an important fruit crop in northern South America. The species C. tamarilloi was described (culture ex-type CBS 129814) by Damm et al. [20] in strains isolated from S. betaceum in Colombia. Damm et al. [20] also described C. laticiphilum and included additional material isolated from leaf of Hevea brasiliensis which was collected in Meta, Colombia. The isolate of this species was not included in our analysis due to the fact that it is a well characterized species. Besides, our SCOPUS search did not find the paper of Damm et al. [20] as a result.

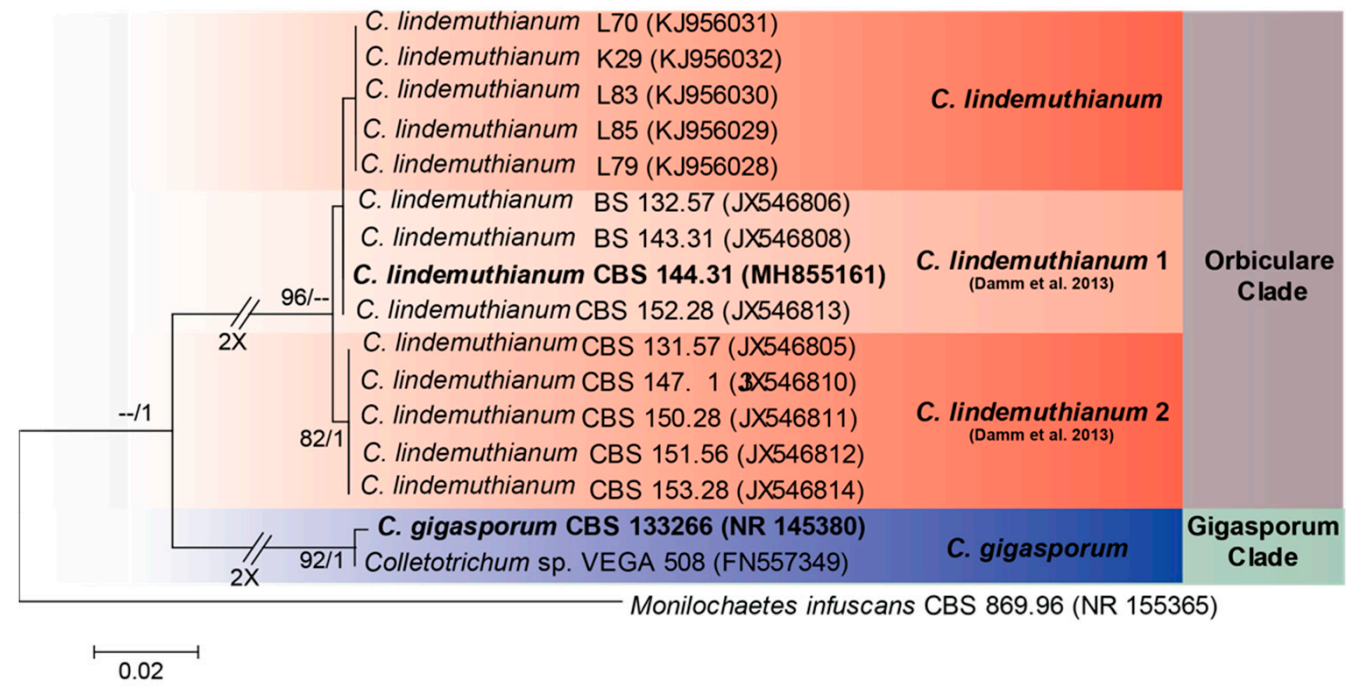

Figure 4. An ML tree of the orbiculare and gigasporum clades that includes species reported in northern South America (Colombia, Ecuador, Peru, and Venezuela). The tree was created based on the alignment of ITS (436 bp). The GenBank accession numbers of sequences retrieved from the database are given in parentheses. Reference strains are presented in bold. Branch lengths are proportional to phylogenetic distance. The best substitution model for ML was determined to be T92+G. Bootstrap support values/Bayesian posterior probability scores above 70\%/0.95 are indicated on the nodes. Clades 1 and 2 of C. lindemuthianum were reported by Damm et al. [19]. The tree was rooted to Monilochaetes infuscans CBS 869.96. ${ }^{\mathrm{T}}$ = Ex-type strain.

In addition, C. coccodes is another species reported in Colombia, Ecuador, and Peru [26]. However, there are no sequences available in the GenBank with which to confirm the identity of this species. Colletotrichum coccodes has been categorized as a singleton species in the genus as a result of do not cluster with any complex [8].

In summary, a total of 22 Colletotrichum species distributed within five complexes (acutatum, boninense, gigasporum, gloeosporioides, and orbiculare) have been reported in northern South America (Table 1). However, studies on the molecular identification of Colletotrichum species in Ecuador, Peru, and Venezuela are limited. Even though Colombian researchers have tried to address this issue, more taxonomic work must be performed in the northern South American region to describe the diversity of the genus in this region. 


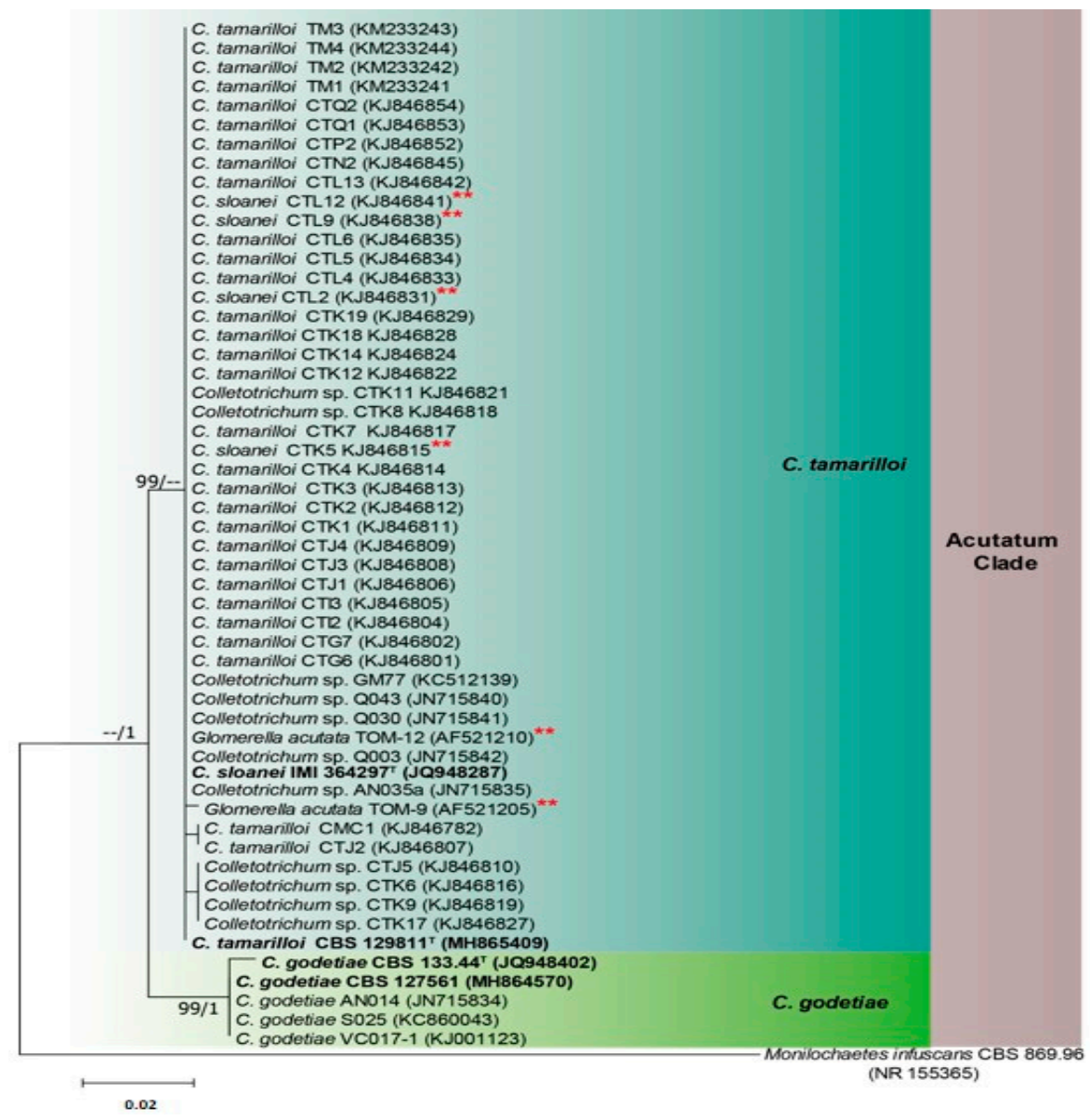

Figure 5. An ML tree of the acutatum clade that includes the species reported in northern South America (Colombia, Ecuador, Peru, and Venezuela). The tree was created based on the alignment of ITS (442 bp). The GenBank accession numbers of sequences retrieved from the database are given in parentheses. Reference strains are presented in bold. Branch lengths are proportional to phylogenetic distance. The best substitution model for ML was determined to be T92. Bootstrap support values/Bayesian posterior probability scores above 70\%/0.95 are indicated on the nodes. The tree was rooted to Monilochaetes infuscans CBS 869.96. ${ }^{\mathrm{T}}=$ Ex-type strain. ${ }^{* *}$ Isolates are probably mislabeled in GenBank.

Table 1. Colletotrichum species reported in Colombia, Ecuador, Peru, and Venezuela.

\begin{tabular}{llll}
\hline Complex & Species & Countries & Observations \\
\hline \multirow{2}{*}{$\begin{array}{l}\text { C. acutatum species } \\
\text { complex }\end{array}$} & C. acutatum & Colombia, Ecuador & \\
& C. godetiae & Colombia & \\
& C. laticiphilum & Colombia & \\
& C. tamarilloi & Colombia, Ecuador & \\
C. boninense species & C. annellatum & Colombia & \\
complex & $\begin{array}{l}\text { C. colombiense } \\
\text { C. boninense }\end{array}$ & Colombia & Colombia \\
& C. karstii & Colombia & \\
\hline $\begin{array}{l}\text { C. gigasporum species } \\
\text { complex }\end{array}$ & C. gigasporum & Colombia & Colombia \\
\hline
\end{tabular}


Table 1. Cont.

\begin{tabular}{llll}
\hline Complex & Species & Countries & Observations \\
\hline & C. aenigma & Colombia & \\
& C. asianum & Colombia & Formerly labeled C. \\
& C. cigarro & Colombia & kahawae \\
C. gloeosporioides & C. fructicola & Colombia & \\
species complex & C. gloeosporioides ss. & Colombia & \\
& C. gloeosporioides sl. & Colombia, Ecuador & \\
& C. gossypii & Colombia & Unverified \\
& C. siamense & Colombia & \\
& C. theobromicola & Colombia & \\
& C. tropicale & Colombia & \\
\hline C. orbiculare species & C. lindemuthianum & Colombia, Peru & Peru \\
complex & C. coccodes & Colombia & Unverified \\
\hline Singleton species & & & \\
\hline ss: sensu stricto. sl: sensu lato. &
\end{tabular}

\subsection{Geographical Distribution of Colletotrichum Complexes in Northern South America}

Of the 71 studies retrieved from the databases, 35 reported Colletotrichum species in the four countries focused upon in this review. Of these, 21 studies reported species in Colombia [18,21-23,27-43], five reported species in Venezuela [44-48], only three reported species in Peru [49-51], and six reported species in Ecuador [52-57].

Pathogens were reported in almost all regions of Colombia, from lowlands (i.e., Afanador-Kafuri et al. [21]) to highlands (i.e., Pardo de la Hoz et al. [28]). The department of Antioquia was the most mentioned. Interestingly, two out of the three studies conducted in Peru focused on the Amazonian region [27,50]. Four studies were performed in the western part of Venezuela in the states of Lara [47], Mérida [44], Trujillo [47] and Zulia $[45,46,48]$, also two studies that did not appear in the SCOPUS databases reported the fungus in the central part of the country in the states of Aragua and Miranda [58,59].

In each country, different hosts were sampled. Very few were reported in several countries, and none were reported in all four countries. Some of the same crops were studied in Colombia and Ecuador and in Colombia and Venezuela. All the crops studied in Ecuador (S. betaceum, Musa spp., R. glaucus and P. vulgaris), except Lupinus mutabilis, were also studied in Colombia. The tamarillo or tree tomato (S. betaceum) was the most common crop studied in both Colombia and Ecuador with the same pathogen species complexes $[21,28,37,53,54,56]$. Only one crop was found in both Venezuela and Colombia: soursop (Annona muricata). Several hosts were found in only one country: the Amazonian fruit camu camu (Myrciaria dubia) was found in Peru [50] as well as pea (Pisum satioum) [51], and lupine (Lupinus mutabilis) was found in Ecuador, while oil palm (Elaeis guineensis) [43] macadamia [60], onion [48] and strawberry (Fragaria $\times$ ananassa) $[44,47]$ were found in Venezuela, and in Colombia were found cotton (Gossypium hirsutum) [18], grape vine (Vitis vinifera) [38], gulupa fruit (Passiflora edulis) [29], heliconia (Heliconia spp.) [32], mango (Mangifera indica) [21,28], Passiflora (Passiflora spp.), rubber (Hevea brasiliensis) [42,61] and pepper (Capsicum annun) [35].

Despite the high diversity of the Colletotrichum hosts studied in previous studies, few complexes (the gloeosporioides, acutatum, boninense, gigasporum and orbiculare species complexes) were identified in the four countries. As expected, the diversity of complexes increased with the number of studies, and Colombia was the country with the highest diversity. Several species are ubiquitous, notably C. gloeosporioides, C. acutatum, and C. lindemuthianum. Interestingly, the species C. karstii was found in different studies investigating different hosts $[21,23]$. 


\subsection{Phytopathological Aspects}

\subsubsection{Hosts, Diversity and Botanical Families}

Colletotrichum is a fungal genus with different pathogenetic, saprophytic, or endophytic relationships with a wide range of hosts (i.e., herbaceous and woody plants) in both agricultural and natural systems within tropical, subtropical and temperate regions [62]. Virtually every crop worldwide is susceptible to one or more Colletotrichum species. All diseases caused by these fungi are characterized by symptoms called anthracnose, including leaf spots, blasts, cankers, postharvest rot, and symptoms in stems, fruits and leaf petioles.

Species belonging to the Colletotrichum genus cause losses of $50 \%-100 \%$ in several economically important crops, particularly fruit trees, vegetables, and ornamentals. Occasionally, the damages caused by Colletotrichum species extend to basic food crops, such as bananas, beans, plantains, yuca (cassava/manioc) and sorghum, which provide livelihoods for a substantial number of farmers in developing countries in tropical and subtropical areas [63]. Colletotrichum species are successful postharvest pathogens because they produce latent infections that start during the preharvest period and are activated once the fruits are stored [64].

In tropical and subtropical countries in the northern South American region, different Colletotrichum species cause diseases in crops of high economic importance. In the reviewed studies, anthracnose and related symptoms were detected in crops from 16 botanical families and 23 species of fruit trees, fodders, ornamentals, leguminous and seasoning plants, and plants intended for industrial use to produce beverages, fibers and oils (Table 2).

Table 2. Families and botanical species in Colombia, Ecuador, Peru, and Venezuela reported to have diseases caused by Colletotrichum species complexes.

\begin{tabular}{|c|c|c|}
\hline Family & Species & Common Name \\
\hline Anacardiaceae & Manguifera indica L. & Mango \\
\hline Annonaceae & Annona muricata L. & Soursop \\
\hline Areacaceae & Elaeis guinensis Jacq. & Oil palm, African palm \\
\hline Caricaceae & Carica papaya $\mathrm{L}$. & Papaya \\
\hline Euphorbiaceae & Hevea brasiliensis Muell. & Rubber \\
\hline Fabaceae & $\begin{array}{l}\text { Phaseolus vulgaris L. } \\
\text { Lupinus mutabilis Sweet } \\
\text { Stylosanthes guianensis Aubl. }\end{array}$ & $\begin{array}{l}\text { Common bean } \\
\text { Tarwi, Lupin, Chocho, } \\
\text { Altramuz } \\
\text { Stylosanthes }\end{array}$ \\
\hline Heliconiaceae & Heliconia spp. & Heliconia, platanillo \\
\hline Lauraceae & Persea americana Mill. & Avocado \\
\hline \multirow{2}{*}{ Malvaceae } & Theobroma cacao L. & Cocoa \\
\hline & Gossypium spp. & Cotton \\
\hline Musaceae & Musa AAB Simmonds & Platane \\
\hline Passifloraceae & Passiflora edulis f. edulis Sims & $\begin{array}{l}\text { Gulupa, Poro poro, purple } \\
\text { passion fruit }\end{array}$ \\
\hline Proteaceae & Macadamia integrifolia & Macadamia \\
\hline Rosaceae & $\begin{array}{l}\text { Rubus glaucus Benth. } \\
\text { Fragaria } \times \text { ananassa }\end{array}$ & $\begin{array}{l}\text { Andean raspberry } \\
\text { Strawberry }\end{array}$ \\
\hline Rubiaceae & Coffea arabica $\mathrm{L}$. & Coffee \\
\hline
\end{tabular}


Table 2. Cont.

\begin{tabular}{|c|c|c|}
\hline Family & Species & Common Name \\
\hline Rutaceae & Citrus latifolia Tanaka & Tahiti Lima \\
\hline \multirow{4}{*}{ Solanaceae } & Capsicum spp. L. & Pepper \\
\hline & Solanum melongena L. & Eggplant \\
\hline & Solanum betaceum Cav. & Tamarillo, tree tomato \\
\hline & Solanum tuberosum & Potato Group Andigena \\
\hline
\end{tabular}

In fruit plants, attacks by Colletotrichum species have been reported in tree tomato (Solanum betaceum) [21,28,56,65,66], mango (Mangifera indica) [21,28,67], Passiflora (Passiflora edulis) [21,29], strawberry (Fragaria $\times$ ananassa) [44,47], blackberry (Rubus glaucus) [23,30-32], plantain (Musa spp.) [36], soursop (Annona muricata) [22,45], avocado (Persea americana) [39,40,43] Tahiti lima (Citrus latifolia) [41,68,69], papaya (Carica papaya) [70], and grape (Vitis vinifera) crops [38].

Regarding leguminous plants, anthracnose has been reported to affect beans (Phaseolus vulgaris) [33,34,71], pea (Pisum sativum) [51], Stylosanthes guianensis [49,72], and lupin (Lupinus mutabilis) [53,73]. Regarding vegetables and tubers, diseases have been reported in yam (Dioscorea spp.) [74], onion (Allium fistulosum) [48] and pepper (Capsicum annuum) plants [75]. Other important plant to consider are ornamental species, such as heliconias [50], seasoning species, such as vanilla (Vanilla planifolia) [76], and plants intended for industrial purposes, such as coffee (Coffea arabica) [25,77], cocoa (Theobroma cacao) [78], cotton (Gossypium hirsutum) [18], and oil palm (Elaeis guineensis) [46], and rubber (Hevea brasiliensis) [42,61].

\subsubsection{Virulence and Aggressiveness}

Manawasinghe et al. [79] propose definitions of pathogenicity based on a summary of the terms used to describe the level of damage caused by pathogens in plants. In the plant pathology field and related areas, pathogenicity is defined as the capacity of a microorganism to produce a disease or to cause damage to a host, and virulence and aggressiveness describe the relative capacity of a microorganism to cause damage to a host [80]. When the pathogen is host-specific, the term "virulence" is used as a quantitative measure of pathogenicity, and in susceptible hosts without specificity, "aggressiveness" is used to refer to quantitative variations in pathogenicity [81]. Based on these definitions, Manawasinghe et al. [82] propose the term "pathogenicity" as a qualitative way to describe the specific character of a particular organism with the capacity to cause a disease.

In the case of Colletotrichum species, which affect a numerous number of hosts, the most accurate term might be "aggressiveness." Only in specific cases might the term "virulence" be valid, such as in the case of C. lindemuthianum in beans and C. gloeosporioides in Stylosanthes, which are known to exhibit variability in terms of pathotype and race.

Artificial methods to test the pathogenicity and/or aggressiveness of plant pathogens are an important part of the process of determining the capacity of a fungus, such as Colletotrichum species, to cause diseases in the plant species from which they were originally isolated or to predict genotypic responses to a disease under field conditions [79]. Specifically, an artificial inoculation method that accurately simulates all natural conditions of the infection should be used to extrapolate the obtained results to the disease under natural pressure in field conditions [83]. Ideally, to test pathogenicity, healthy plants from the same species should be inoculated without wounds and to assess virulence, wounds can be used. For the pathogen, aspersion of aqueous suspensions or drops from conidia, or agar plugs with mycelium can be used. These tests can be performed either under controlled conditions in a laboratory or greenhouse or under field conditions. In either case, several environmental factors, temperature, relative humidity, might influence the 
artificial inoculation process. In addition, the obtained results depend on the size, age and resistance level of the host [83].

Studies have tested the pathogenicity and measured the aggressiveness of Colletotrichum species, which have been reported to be plant pathogens in countries such as Colombia, Ecuador, Peru and Venezuela. These studies used a variety of inoculation methods and obtained a range of different results regarding aggressiveness and virulence from the different species and/or isolates being tested. No consensus was achieved concerning the terminology used to describe the response or behavior of the Colletotrichum species tested, including "pathogenicity." According to the definition presented above, "pathogenicity" refers to the capacity of the tested species to cause disease in the host from where it was initially isolated, in line with Koch's postulates [36].

Certain studies clearly describe the difference between "pathogenicity" and "virulence." For example, Sicard et al. [52] distinguish between a pathogenicity test, which was to be performed in a highly susceptible host, and a test of virulence diversity based on the results obtained for 12 different genotypes of beans with different genetic levels of resistance to anthracnose. The authors identified three groups within the pathogen population based on the isolates' response to the hosts' genes.

Rueda-Hernández et al. [30] performed a pathogenicity test (which confirmed Koch's postulates) of Colletotrichum isolates belonging to the C. gloeosporioides complex and C. acutatum complex that were found in Andean blackberry plants. The term "pathogenicity" is well used according to the description above, and terms such as "latency period" and "incubation period" are introduced in order to establish differences within and between the Colletotrichum species complexes. Therefore, the authors performed a quantitative evaluation of the fungus's capacity to cause disease depending on o the fungus species and the host genotype.

In the same study [30], the authors evaluate differences in pathogenicity between samples inoculated using different methods (i.e., wound-mediated vs. woundless inoculation). They conclude that certain differences exist in the capacity of the two species complexes to cause infection; the Colletotrichum gloeosporioides species complex has the capacity to cause infection in both wounded and woundless tissues, while the C. acutatum species complex can infect only wounded tissues. These results are interesting considering that most of the isolates from the C. acutatum complex were obtained from stem tissues, which are the first tissues to be affected in the field.

The results of Rueda-Hernández et al. [30] align with those of Afanador-Kafuri et al. [21], who performed a study with Colletotrichum species obtained from blackberry plants in eight productive areas of Colombia and found that the C. acutatum species complex has a lower infection capacity in stems when the wound-mediated inoculation method is used. AfanadorKafuri et al. [23] concluded that the differences they found between the C. acutatum and C. gloeosporioides species complexes (in terms of their infection capacity in blackberry stems) are due to differences in the colonization strategy applied in different tissues of the plant. Colletotrichum acutatum is found more often in flower and fruit tissues, while C. gloeosporioides seems to prefer stems. Moreover, the authors highlight differences in the kind of blackberry (i.e., spiny, or spineless) from which the species complexes were isolated, which is important to consider because there are several anatomical and structural disparities between the two analyzed ecotypes. In spineless blackberry ecotypes, Afanador-Kafuri et al. [23] observed a prevalence of species within the $C$. acutatum complex, which are mainly associated with symptoms of inflorescence and fruits while stems are free from disease. In the spiny ecotype, the $C$. gloeosporioides complex was prevalent. These results support those of López-Vasquez et al. [32], who found that spiny plants had greater susceptibility than spineless plants or genotypes, as the later showed total resistance to artificial inoculation of $C$. gloeosporioides isolates under field conditions.

These studies illustrate the presence of different infection mechanisms among Colletotrichum species belonging to both the $C$. gloeosporioides and C. acutatum complexes. Those mechanisms seem to be closely related to the original host genotype and the host's morpho- 
logical and anatomical characteristics. In some cases, wounds, even imperceptible ones, are necessary for penetration of the pathogen. Thus, studies of pathogenicity, aggressiveness, and virulence must consider differences in inoculation methods (i.e., wound-mediated or woundless) and in plant tissues, as well as the characterization of the infection cycle.

\subsubsection{Host Specificity}

The Colletotrichum genus is an important pathogen worldwide due to its capacity to colonize and infect an extensive range of hosts in different families and botanical species. This capacity seems to be closely associated with speciation in this fungal genus, which may be due to changes in its behavior $[5,84]$.

There are significant differences between phytopathogenic fungi in terms of the number and diversity of hosts they can infect and/or colonize. Fungal plant pathogens may be classified as "specialists" if they infect only one plant species or a narrowly related, restricted group or as "generalists" if they can infect a wide range of plants in several environments. However, it is rare to find both fungal categories within the same phylogenetic lineage or fungal genus, as is the case for the Colletotrichum genus. A specialist species found in the northern part of South America is C. lindemuthianum, which has been described only in beans (Phaseolus vulgaris) in Colombia [33,34] and Ecuador [52].

Studies of fruit trees in Colombia, such as the Andean blackberry, grape, tree tomato, and soursop, have demonstrated the coexistence of different Colletotrichum species in the same host, not only those belonging to the C. acutatum complex but also those from the $C$. gloeosporioides and C. boninense complexes. For instance, in a study aiming to characterize the causal agent of fruit deformation in grape plants, Lopez-Zapata et al. [35] report that two species (C. aenigma and C. siamense in the gloeosporioides clade) were attacking the same host. Similarly, Afanador-Kafuri et al. [23] report that Colletotrichum species belonging to the C. gloeosporioides (C. cigarro (formerly C. kahawae subsp. ciggaro) and C. fruticola), C. acutatum (C. godetiae, and Colletotrichum sp.) and C. boninense (C. brassicicola and I) complexes were attacking the same Andean blackberry host, but in different tissues. Species in the C. acutatum complex show a preference for fruits and flowers, while those in the C. gloesosporioides and I complexes prefer stem tissues. Similar results have been found for soursop, a fruit tree in which disease is caused by species belonging to the $C$. gloesporioides (C. theobromicola, C. tropicale, C. siamense and Colletotrichum sp.), C. acutatum (Colletotrichum sp.), and C. boninense (C. karstii and Colletotrichum sp.) complexes. These species show differences in their capacity to cause disease; C. tropicale and C. theobromicola were found to be most aggressive.

A study conducted in Ecuador by Falconi et al. [73] shows that isolates belonging to the same Colletotrichum species can have host preferences or differential adaptations. This study focuses on the pathogenetic, molecular, and morphological characterization of $C$. acutatum isolates that cause anthracnose in tree tomato and lupin plants. The results of this study enable classification of isolates into two populations based on their specificity and strategy for attacking the host (biotrophic vs. necrotrophic) and on phylogenetic analysis of the ITS sequences. One population includes tree tomato isolates and one lupin isolate, and the other population consists of only lupin isolates. The host range assays indicate that each of these two species of plants is attacked by a population of C. acutatum that has adapted to the species. Based on the symptoms and lesion sizes observed in each host, the authors conclude that the isolates were more aggressive in their original hosts but pathogenetic in their alternative hosts, so host adaptation is more likely to be quantitative than qualitative.

Studies of mango and tree tomato crops in Colombia have found that isolates of species belonging to the C. gloeosporioides, C. acutatum, and C. boninense complexes did not exhibit host preference or specificity. Nevertheless, some differences between isolates in terms of their aggressiveness (i.e., ability to cause lesions) and dissemination capacity (i.e., sporulation on the affected tissue) have been observed [65]. This led authors to suggest that the lack of host specificity in these Colletotrichum species may favor the migration of populations from one host to another, which might be a threat to these two crops in 
Colombia. In addition, considering that the evaluated species exhibited higher sporulation capacity in alternative hosts, their dissemination capacity might be more related to their survival strategy under adverse conditions, which can allow the fungus to generate a larger number of propagules, rather than host adaptation. These findings support the final analyses of Cabrera et al. [65], who state that categorization of Colletotrichum species into generalists and specialists is very simplistic and the reality might be more complex.

Therefore, it is necessary to consider and evaluate other criteria to clarify the mechanisms involved in host preference or specificity within Colletotrichum species. Baroncelli et al. [84] found an association between broad host range and gene content changes in the Colletotrichum genus (C. acutatum and C. gloeosporiodes species complexes). In addition, Liang et al. [85] state that species in the Colletotrichum genus could share new and conserved virulence factors, which are built in a lineage-specific way and allow the pathogen to adapt to a particular host and tissue. The authors suggest that it is critical to identify these virulence factors and their evolution in order to control diseases caused by Colletotrichum species and better understand of the fundamental mechanisms of the plant-pathogen interaction.

\subsubsection{Strategies for Controlling Colletotrichum Species in Northern South America}

Plant diseases challenge the ability of agriculture to provide adequate amounts of food for an increasing population [86,87]. There are two approaches to address this issue, each of which has advantages and disadvantages. The first is using agrochemicals, which have been questioned recently due to their lateral effects on the environment and animal health $[87,88]$. The second is to use alternative methods, such as integrated crop management, organic farming, conventional plant breeding, genetic engineering and biocontrol [87,88]. Bacteria and fungi used for biocontrol have been obtained from diverse sources, including compost [89], the rhizosphere [90], seeds [91] and inside plants (endophytes) [92] (for a more thorough review of these topics, see De Silva et al. [88]).

Our literature review revealed several articles that discussed methods of controlling Colletotrichum species. Of these, 17 were conducted in Colombia, three in Venezuela, one in Ecuador, and two in Peru. The Colombian studies mainly performed agrochemicals evaluations [93] or in vitro evaluations of natural products, such as essential oils and metabolites obtained from plants [35,49,94-98] and from microorganisms [42,99-101]. In addition, we found an article evaluating the in vitro effect of a bacterium and its cell-free culture filtrate [27], an article evaluating resistance to anthracnose for plant breeding [32], and an article evaluating climatological conditions and the incidence of anthracnose [102]. The Venezuelan studies mostly performed in vitro evaluations of extracts, including tests on detached fruits [47,103] and propolis ethanolic extract [104]. The Ecuadorian article evaluated plants' resistance to anthracnose [47], and both Peruvian articles examined chemical control [50,51].

The studies conducted in northern South America to examine methods of controlling anthracnose do not have a homogeneous approach, although the main goal is to find new molecules that could eventually substitute the old agrochemical molecules. This is a common approach, and it is probably based on fear that more "biological" approaches (i.e., those using microorganisms) will be less efficient. The international literature includes many studies of the use of microorganisms for controlling anthracnose induced by Colletotrichum [105-108], then it is expectable that performing further research in northern South American countries could increase the range of options to control this limiting disease.

\subsection{Colletotrichum Species as Endophytes}

Recent studies aiming to determine the behaviors of fungi considered fungi isolated from infected tissue to be pathogens, those isolated from healthy tissue to be endophytes, and those isolated from dead vegetable material to be saprophytes. Most Colletotrichum species are important phytopathogens for different crops, although some are endophytes 
or saprophytes. The endophytic lifestyle of Colletotrichum species has been described in various countries, particularly in relation to tropical trees and grasses $[109,110]$.

In the northern South American region, only a few hosts have been reported to harbor Colletotrichum as an endophyte. In Venezuela, C. gloeosporioides was isolated from the Haden variety of mango (Mangifera indica) in the eastern part of the country [67] and from floral buds of Psidium guajava [111]. Recently, two isolates of $C$. gloeosporioides s.l. were obtained as endophytes from cacao leaves (Theobroma cacao) in two localities (Naranjal and Balao) in the province of Guayas, Ecuador. They were tested for the capacity to control the growth of Moniliophthora roreri and M. perniciosa, two of the main pathogens affecting cacao crops [78]. In Colombia, three main hosts have been reported for endophyte Colletotrichum species: vanilla, coffee and mango. In a study aiming to identify the fungal endophytes associated with vanilla species, Gamboa-Gaitán [76] reported the presence of $C$. boninense in the stems of Vanilla planifolia, while C. gloeosporioides was isolated from leaves. In addition, Vega et al. [77] found that Colletotrichum was the dominant genus in a fungal endophytic community of Coffea arabica in Colombia. Indeed, 106 out of a total of 267 endophytic fungal (Colletotrichum) isolates were obtained from the leaves $(n=78)$, berries $(n=2)$, crowns $(n=15)$, peduncles $(n=11)$, and stems $(n=22)$ of coffee in one location in Colombia. After molecular characterization based on the ITS region, the isolates were distributed into 25 genotypes, and they showed an unexpected diversity [77]. In a mango cultivar (M. indica cultivar Azucar), Quintero-Mercado et al. [112] reported eight isolates from leaves and just one from a branch. The pathogenic potential of these entophytic isolates in mango fruits was evaluated, and all nine isolates were found to have the capacity to produce lesions. Just the most virulent isolate was identified and corresponded to $C$. tropicale.

The fact that Colletotrichum can be isolated as an endophyte from different plants may be due to the fact that an endophytic behavior could be confused with the initial phase of the pathogenic cycle involved in a hemibiotrophic lifestyle when the host exhibits no symptoms [108]. In northern South America, more evidence is needed to determine whether Colletotrichum species can behave as latent pathogens, hemibiotrophs, or endophytes and whether these species have a wider host range as endophytes than they do as pathogens, as was reported in Panama [113].

\section{Conclusions}

This review is not a taxonomic study of the genus Colletotrichum in the northern South American region. The studies reviewed in this manuscript vary in terms of the rigorousness with which formal identification of the isolated samples was conducted. Some studies performed morphological identification, while others used multi-locus phylogeny to identify isolates at the species level. For this reason, we decided to start this review with a robust phylogenetic analysis of the Colletotrichum isolates reported in the region, although limited by the availability of the corresponding sequences. In this way, researchers in the region can realize that many of the isolates could be misidentified or mislabeled. This does not allow us to know what species are really associated with crops in the northern South American region. Our results showed that, to date, five complexes have been reported in northern South American crops.

There was also high variability in terms of inoculation methodologies. Some studies employed wound-mediated inoculation, while others preferred to not damage the plant material. We believe that this is important to consider since wounds hinder identification of the pathogenicity of the isolate and thus no definitive conclusions can be made regarding the host range of the species. Despite this, we conclude that host specificity is not always present in Colletotrichum isolates, but a host preference can sometimes be observed. This is particularly important in countries with high plant biodiversity and in which crops are present in a field all year long and share pathogens.

In addition, we found a disparity in the number of studies conducted in each country and a lack of continuity in the studies. It is worth noting that the studies conducted in Colombia and Ecuador cover a wide range of years, while just one study in Venezuela [48] 
and one in Peru were conducted recently [51]. For each crop, few studies have been published in each country. In our opinion, more studies should study the diversity and its geographical distribution of the pathogen's isolates. This information helps to guide the control strategies, for example the deployment of resistant genotypes. More studies are also needed on biological control or other alternative methods of control, as an option to chemical control.

Supplementary Materials: The following supporting information can be downloaded at: https: //www.mdpi.com/article/10.3390/agronomy12030548/s1. Table S1. Studies reviewed in this manuscript to obtain the data presented [114].

Author Contributions: Conceptualization, S.R. and P.J.; methodology, M.G.-S., M.C. and S.R.; formal analysis, M.G.-S., M.C., P.J., L.A.-K. and S.R.; writing—original draft preparation, M.G.-S., M.C., P.J., L.A.-K. and S.R.; writing-review and editing, M.G.-S., M.C., P.J., L.A.-K. and S.R. All authors have read and agreed to the published version of the manuscript.

Funding: This research was funded by the Vice Presidency of Research \& Creation's Publication at Universidad de los Andes for its financial support.

Conflicts of Interest: No conflict of interest is declared.

\section{References}

1. Sutton, B.C. The Genus Glomerella and Its Anamorph Colletotrichum, 1st ed.; CAB International: Wallingford, UK, $1992 ;$ pp. 1-26.

2. O'Connell, R.J.; Thon, M.R.; Hacquard, S.; Amyotte, S.G.; Kleemann, J.; Torres, M.F.; Damm, U.; Buiate, E.A.; Epstein, L.; Alkan, N.; et al. Lifestyle transitions in plant pathogenic Colletotrichum fungi deciphered by genome and transcriptome analyses. Nat. Genet. 2012, 44, 1060-1065. [CrossRef]

3. Damm, U.; Sato, T.; Alizadeh, A.; Groenewald, J.Z.; Crous, P.W. The Colletotrichum dracaenophilum, C. ámagnum and C. áorchidearum species complexes. Stud. Mycol. 2019, 92,1-46. [CrossRef] [PubMed]

4. Liu, F.; Cai, L.; Crous, P.W.; Damm, U. The Colletotrichum gigasporum species complex. Persoonia 2014, 33, 83-97. [CrossRef] [PubMed]

5. Cannon, P.F.; Damm, U.; Johnston, P.R.; Weir, B.S. Colletotrichum-Current status and future directions. Stud. Mycol. 2012, 73, 181-213. [CrossRef] [PubMed]

6. Corda, A.C.I. Die pilze Deutschlands. In Deutschlands Flora in Abbildungen nach der Natur mit Beschreibungen, 3rd ed.; Sturm, J., Ed.; Tables 21-32; Sturm: Nürnberg, Germany, 1831; Volume 12, pp. 33-64.

7. Jayawardena, R.S.; Hyde, K.D.; Damm, U.; Cai, L.; Liu, M.; Li, X.H.; Zhabg, W.; Zhao, W.S.; Yan, J.Y. Notes on currently accepted species of Colletotrichum. Mycosphere 2016, 7, 1192-1260. [CrossRef]

8. Talhinhas, P.; Baroncelli, R. Colletotrichum species and complexes: Geographic distribution, host range and conservation status. Fungal Divers. 2021, 110, 109-198. [CrossRef]

9. Weir, B.S.; Johnston, P.R.; Damm, U. The Colletotrichum gloeosporioides species complex. Stud. Mycol. 2012, 73, 115-180. [CrossRef] [PubMed]

10. Liu, F.; Damm, U.; Cai, L.; Crous, P.W. Species of the Colletotrichum gloeosporioides complex associated with anthracnose diseases of Proteaceae. Fungal Divers. 2013, 61, 89-105. [CrossRef]

11. Tamura, K.; Stecher, G.; Peterson, D.; Filipski, A.; Kumar, S. MEGA6: Molecular evolutionary genetics analysis version 6.0. Mol. Biol. Evol. 2013, 30, 2725-2729. [CrossRef]

12. Ronquist, F.; Huelsenbeck, J.P. MrBayes 3: Bayesian phylogenetic inference under mixed models. Bioinformatics 2003, 19, 1572-1574 [CrossRef]

13. Darriba, D.; Taboada, G.L.; Doallo, R.; Posada, D. jModelTest 2: More models, new heuristics and parallel computing. Nat. Methods 2012, 9, 772. [CrossRef] [PubMed]

14. Guindon, S.; Gascuel, O. A simple, fast, and accurate algorithm to estimate large phylogenies by maximum likelihood. Syst. Biol. 2003, 52, 696-704. [CrossRef] [PubMed]

15. Hyde, K.D.; Nilsson, R.H.; Alias, S.A.; Ariyawansa, H.A.; Blair, J.E.; Cai, L.; de Cock, A.W.A.M.; Dissanayake, J.; Glockling, S.L.; Goonasekara, I.D.; et al. One stop shop: Backbones trees for important phytopathogenic genera: I (2014). Fungal Divers. 2014, 67, 21-125. [CrossRef]

16. Doyle, V.P.; Oudemans, P.V.; Rehner, S.A.; Litt, A. Habitat and host indicate lineage identity in Colletotrichum gloeosporioides s.1. from wild and agricultural landscapes in North America. PLoS ONE 2013, 8, e62394. [CrossRef]

17. Cabral, A.; Azinheira, H.G.; Talhinhas, P.; Batista, D.; Ramos, A.P.; Silva, M.D.C.; Oliveira, H.; Várzea, V. Pathological, morphological, cytogenomic, biochemical and molecular data support the distinction between Colletotrichum cigarro comb. et stat. nov. and Colletotrichum kahawae. Plants 2020, 9, 502. [CrossRef]

18. Moreno-Moran, M.; Burbano-Figueroa, O. First report of Colletotrichum gossypii var. cephalosporioides causing cotton ramulosis in Colombia. Plant Dis. 2016, 100, 653. [CrossRef] 
19. Fu, M.; Crous, P.W.; Bai, Q.; Zhang, P.F.; Xiang, J.; Guo, Y.S.; Zhao, F.F.; Yang, M.M.; Hong, N.; Xu, W.X.; et al. Colletotrichum species associated with anthracnose of Pyrus spp. in China. Persoonia 2018, 42, 1-35. [CrossRef]

20. Damm, U.; Cannon, P.F.; Woudenberg, J.H.C.; Johnston, P.R.; Weir, B.S.; Tan, Y.P.; Shivas, R.G.; Crous, P.W. The Colletotrichum boninense species complex. Stud. Mycol. 2012, 73, 37-113. [CrossRef]

21. Afanador-Kafuri, L.; Minz, D.; Maymon, M.; Freeman, S. Characterization of Colletotrichum isolates from tamarillo, Passiflora, and mango in Colombia and identification of a unique species from the genus. Phytopathology 2003, 93, 579-587. [CrossRef]

22. Álvarez, E.; Gañán, L.; Rojas-Triviño, A.; Mejía, J.F.; Llano, G.A.; González, A. Diversity and pathogenicity of Colletotrichum species isolated from soursop in Colombia. Eur. J. Plant Pathol. 2014, 139, 325-338. [CrossRef]

23. Afanador-Kafuri, L.; González, A.; Gañán, L.; Mejía, J.F.; Cardona, N.; Alvarez, E. Characterization of the Colletotrichum species causing anthracnose in Andean blackberry in Colombia. Plant Dis. 2014, 98, 1503-1513. [CrossRef] [PubMed]

24. Damm, U.; Cannon, P.F.; Liu, F.; Barreto, R.W.; Guatimosim, E.; Crous, P.W. The Colletotrichum orbiculare species complex: Important pathogens of field crops and weeds. Fungal Divers. 2013, 61, 29-59. [CrossRef]

25. Rakotoniriana, E.F.; Scauflaire, J.; Rabemanantsoa, C.; Urveg-Ratsimamanga, S.; Corbisier, A.M.; Quetin-Leclercq, J.; Declerck, S.; Munaut, F. Colletotrichum gigasporum sp. nov.: A new species of Colletotrichum producing long straight conidia. Mycol. Prog. 2013, 12, 403-412. [CrossRef]

26. Nitzan, N.; Quick, R.A.; Hutson, W.D.; Bamberg, J.; Brown, C.R. Partial resistance to potato black dot, caused by Colletotrichum coccodes in Solanum tuberosum group Andigena. Am. J. Potato Res. 2010, 87, 502-508. [CrossRef]

27. Kelemu, S.; Badel, J.L. In vitro inhibition of Colletotrichum gloeosporioides and other phytopathogenic fungi by an Amazonian isolate of Bacillus subtilis and its cell-free culture filtrate. Australas. Plant Pathol. 1994, 23, 41-45. [CrossRef]

28. Pardo-De la Hoz, C.J.; Calderón, C.; Rincón, A.M.; Cárdenas, M.; Danies, G.; López-Kleine, L.; Restrepo, S.; Jiménez, P. Species from the Colletotrichum acutatum; Colletotrichum boninense and Colletotrichum gloeosporioides species complexes associated with tree tomato and mango crops in Colombia. Plant Pathol. 2016, 65, 227-237. [CrossRef]

29. Ramírez, J.G.; Tamayo, P.J.; Morales, J.G. Identification and pathogenicity of microorganisms affecting purple passion fruit in Colombia. Rev. Ceres. 2017, 64, 250-257. [CrossRef]

30. Rueda-Hernández, K.R.; Cardona, A.S.; Cadavid-Restrepo, G.E.; Benjumea, C.I.S.; Gutierrez, G.P.C.; Isaza, R.E.A. Differential organ distribution, pathogenicity and benomyl sensitivity of Colletotrichum spp. from blackberry plants in Northern Colombia. J. Phytopathol. 2013, 161, 246-253. [CrossRef]

31. Marulanda, M.L.; López, A.M.; Isaza, L.; López, P. Microsatellite isolation and characterization for Colletotrichum spp., causal agent of anthracnose in Andean blackberry. Genet. Mol. Res. 2014, 13, 7673-7685. [CrossRef]

32. López-Vásquez, J.M.; Castaño-Zapata, J.; Marulanda-Ángel, M.L.; López-Gutiérrez, A.M. Characterization of Anthracnose resistance caused by Glomerella cingulata and productivity of five Andean blackberry genotypes (Rubus glaucus Benth). Acta Agronómica 2013, 62, 174-185.

33. Vanegas-Berrouet, K.M.; Gutierrez, P.A.; Marín, M.A. Identificación molecular de hongos aislados de tejidos de fríjol con síntomas de antracnosis. Acta Biológica Colomb. 2014, 19, 143-153.

34. Martínez, L.; Vanegas- Berrouet, K.; Salazar, M.; Gutiérrez, P.; Marín, M. Detección por PCR de Colletotrichum lindemuthianum en cultivos y semillas de frijol en Antioquia, Colombia. Acta Agronómica 2014, 63, 377-387. [CrossRef]

35. Tofiño-Rivera, A.; Chinchilla-Sánchez, K.; Ortega-Cuadros, M. Evaluación in vitro de compatibilidad de agroquímicos, bioinsumos y aceite esencial sobre el control de Colletotrichum gloeosporioides aislado de ají. Vitae 2016, 23, S478.

36. Viveros-Folleco, Y.M.; Guzmán-Piedrahita, Ó.A.; Villegas-Estrada, B. Enfermedades en viveros comerciales de Musa AAB “Dominico Hartón" en el departamento de Caldas, Colombia. Bol. Cient. Cent. Mus. Mus. Hist. Nat. 2017, 212, 61-80.

37. Rojas, P.; Pardo-De la Hoz, C.J.; Calderón, C.; Vargas, N.; Cabrera, L.A.; Restrepo, S.; Jiménez, P. First report of Colletotrichum kahawae subsp. ciggaro causing anthracnose disease on tree tomato in Cundinamarca, Colombia. Plant Dis. 2018, $102,2031$. [CrossRef]

38. López-Zapata, S.P.; Castaño-Zapata, J.; Arango-Isaza, R.; Vásquez-Barajas, D.A. Characterization of the causal agent of the deformation of the fruits of the grape Vitis vinifera L. var. Red Globe, in La Unión, Valle del Cauca, Colombia. Rev. Acad. Colomb. Cienc. Exact. Fis. Nat. 2019, 43, 241-249. [CrossRef]

39. Ramírez-Gil, J.G.; Peterson, A.T. Current and potential distributions of the most important diseases affecting Hass avocado in Antioquia Colombia. J. Plant Prot. Res. 2019, 59, 214-228. [CrossRef]

40. Ramírez-Gil, J.G.; Morales, J.G. Polyphasic identification of preharvest pathologies and disorders in avocado cv. Hass. Agron. Colomb. 2019, 37, 213-227. [CrossRef]

41. Botina, A.; García, B.L.M.; Romero, Y. Pre-and post-harvest factors that affect the quality and commercialization of the Tahiti lime. Sci. Hortic. 2019, 257, 108737. [CrossRef]

42. Castañeda-Novoa, C.D.; Vinchira-Villarraga, D.M.; Romero, I.A.G.; Moreno-Sarmiento, N. Evaluation of the production of antifungal metabolites against Colletotrichum gloeosporioides in Streptomyces 5.1 by random mutagenesis. Acta Sci. Biol. Sci. 2021, 43, e54709. [CrossRef]

43. Ramírez-Gil, J.G.; Osorio, J.G.M. Source of inoculum of pathogens, the origin of disorders and diseases management in avocado nurseries. Australas. Plant Pathol. 2021, 50, 457-468. [CrossRef]

44. Cedeño, L.; Carrero, C. Antracnosis causada por Colletotrichum acutatum en frutos de fresa en Mérida, Venezuela. Interciencia 1997, $22,315-319$. 
45. Andrades, I.; Yender, F.; Labarca, J.; Ulacio, D.; Paredes, C.; Marín, Y. Evaluación de la antracnosis Colletotrichum sp. en guanábana Annona muricata L. tipo Gigante en el sector Moralito del estado Zulia, Venezuela. Rev. Cient. UDO Agríc. $2009,9,148-157$.

46. Domínguez-Guerrero, I.P.; Mohali-Castillo, S.R.; Marín-Montoya, M.A.; Pino-Menesini, H.B. Characterization and genetic variability of Colletotrichum gloeosporioides sensu lato in oil palm (Elaeis guineensis Jacq.) plantations from Venezuela. Trop. Plant Pathol. 2012, 37, 108-122.

47. Urdaneta, L.; Sanabria, M.; Rodríguez, D.; de Camacaro, M.P. Antracnosis causada por Colletotrichum acutatum Simmonds en frutos de fresa en los estados de Lara y Trujillo, Venezuela. Rev. Fac. Agron. 2013, 30, 504-528.

48. Arocha, I.; Hernández, S.; Araujo, D.; Colina, A. Hongos asociados al cultivo de la cebolla (Allium fistulosum L.) en los municipios Jesús Enrique Lossada y Maracaibo, estado Zulia, Venezuela. Rev. Fac. Agron. Univ. Zulia. 2020, 37, 78-88. Available online: https://produccioncientificaluz.org/index.php/agronomia/article/view/32993 (accessed on 5 December 2021).

49. Kelemu, S.; Skinner, D.Z.; Badel, J.L.; Moreno, C.X.; Rodríguez, M.X.; Fernandes, C.D.; Charchar, M.J.; Chakraborty, S. Genetic diversity in South American Colletotrichum gloeosporioides isolates from Stylosanthes guianensis, a tropical forage legume. Eur. J. Plant Pathol. 1999, 105, 261-272. [CrossRef]

50. Perez, D.; Iannacone, J. Control Químico de la Antracnosis Causado por Colletotrichum gloeosporioides en el Cultivo del Camu Camu (Myrciaria dubia Myrtaceae) en Ucayali, Perú. Fitopatol. Bras. 2006, 31, 518. [CrossRef]

51. Aguilar, R.; Rafael-Rutte, R.; Martínez-Santos, H.; Apaza-Apaza, S. Agente causal de la antracnosis en el cultivo de arveja (Pisum sativum L.) en el norte de Perú: Sintomatología, aislamiento e identificación, patogenicidad y control. Sci. Agropecu. 2021, 12, 7-14. [CrossRef]

52. Sicard, D.; Michalakis, Y.; Dron, M.; Neema, C. Genetic diversity and pathogenic variation of Colletotrichum lindemuthianum in the three centers of diversity of its host, Phaseolus vulgaris. Phytopathology 1997, 87, 807-813. [CrossRef]

53. Falconi, C.E.; Visser, R.G.; van Heusden, S. Influence of plant growth stage on resistance to anthracnose in Andean lupin (Lupinus mutabilis). Crop Pasture Sci. 2015, 66, 729-734. [CrossRef]

54. Schütz, L. Survey of agricultural practices and alternatives to pesticide use to conserve water resources in the Mojanda Watershed, Ecuador. Future Food J. Food Agric. Soc. 2014, 2, 56-66.

55. Valencia-Chamorro, S.; Guevara, J.; Paez, D.; Villaplana, R. Hongos caudantes de podedumbres en la pocosecha de Mora (Rubus glaucus): Aislamiento, identificación y evaluación del género más agresivo. Vitae 2016, 23, S769-S773.

56. Caicedo, J.D.; Lalangui, K.P.; Pozo, A.N.; Cevallos, P.A.; Arahana, V.S.; Méndez, K.S. Multilocus molecular identification and phylogenetic analysis of Colletotrichum tamarilloi as the causal agent of Tamarillo Solanum betaceum anthracnose in the Ecuadorian highlands. Eur. J. Plant Pathol. 2017, 148, 983-996. [CrossRef]

57. Riera, N.; Ramirez-Villacis, D.; Barriga-Medina, N.; Alvarez-Santana, J.; Herrera, K.; Ruales, C.; Leon-Reyes, A. First report of banana anthracnose caused by Colletotrichum gloeosporioides in Ecuador. Plant Dis. 2019, 103, 763. [CrossRef]

58. Guevara, Y.; Aponte, A.; Masselli, A. Enfermedades del cultivo de la fresa en dos localidades agrícolas de Aragua y Miranda. INIA Divulga 2004, 3, 22-24.

59. Farrera, P.; Zambrano, V.; Ortiz, M. Identificación de hongos asociados a enfermedades del fruto de la fresa en el municipio Jáuregui del estado Táchira. Rev. Fac. Agron. 2007, 24, 269-281.

60. Cedeño, L.; Carrero, C. Antracnosis en plántulas de macadamia causada por Glomerella cingulata. Interciencia 2002, $27,559-562$.

61. Castro-Navarro, O.M.; Riascos-Ortiz, D.H.; Hoyos-Carvajal, L.M.; Tapiero-Ortiz, A.L. Disturbios histológicos causados por Microcyclus ulei y el complejo Colletotrichum spp. en caucho (Hevea brasiliensis). Summa Phytopathol. 2020, 46, 105-112. [CrossRef]

62. Bailey, J.A.; O'connell, R.J.; Pring, R.J.; Nash, C. Infection Strategies of Colletotrichum Species; CAB International: Wallingford, UK, 1992; pp. 88-120.

63. Dean, R.; Van Kan, J.A.; Pretorius, Z.A.; Hammond-Kosack, K.E.; Di Pietro, A.; Spanu, P.D.; Rudd, J.J.; Dickman, M.; Kahmann, R.; Ellis, J.; et al. The Top 10 fungal pathogens in molecular plant pathology. Mol. Plant Pathol. 2012, 13, 414-430. [CrossRef]

64. Prusky, D.; Alkan, N.; Mengiste, T.; Fluhr, R. Quiescent and necrotrophic lifestyle choice during postharvest disease development. Annu. Rev. Phytopathol. 2013, 51, 155-176. [CrossRef] [PubMed]

65. Cabrera, L.; Rojas, P.; Rojas, S.; Pardo-De la Hoz, C.J.; Mideros, M.F.; Danies, G.; Lopez-Kleine, L.; Jiménez, P.; Restrepo, S. Most Colletotrichum species associated with tree tomato Solanum betaceum and mango Mangifera indica crops are not host-specific. Plant Pathol. 2018, 67, 1022-1030. [CrossRef]

66. Viera, W.; Sotomayor, A.; Tamba Sandoval, M.V.; Vásquez, C.; Martínez, A.; Ron, L. Estimación de parámetros de calidad del fruto para segregantes interespecíficos de tomate de árbol Solanum betaceum Cav. en respuesta de resistencia a la Antracnosis (Colletotrichum acutatum J.H. Simmonds). Acta Agronómica 2016, 65, 304-311. [CrossRef]

67. Morales, V.; Rodriguez, M. Micobiota endofítica asociada al cultivo del mango 'Haden' Mangifera indica L. en el oriente de Venezuela. Rev. UDO Agríc. 2009, 9, 393-402.

68. Mogollón, Á.M.; López, C.N.; Orduz, J.O. Efecto de las variables meteorológicas sobre la antracnosis (Colletotrichum acutatum) de la lima ácida Tahití en el piedemonte llanero, Colombia. Rev. Acad. Colomb. Cienc. Ex. Fis. Nat. 2021, 45, 250-259. [CrossRef]

69. Ramírez-Pelayo, C.; Martínez-Quiñones, J.; Gil, J.; Durango, D. Coumarins from the peel of citrus grown in Colombia: Composition, elicitation and antifungal activity. Heliyon 2019, 5, e01937. [CrossRef]

70. Martinez, J.; Gomez, A.; Ramirez, C.; Gil, J.; Durango, D. Controlling anthracnose by means of extracts, and their major constituents, from Brosimum rubescens Taub. Biotechnol. Rep. 2020, 25, e00405. [CrossRef] 
71. Balardin, R.S.; Kelly, J.D. Interaction between Colletotrichum lindemuthianum races and gene pool diversity in Phaseolus vulgaris. J. Am. Soc. Hortic. Sci. 1998, 123, 1038-1047. [CrossRef]

72. Weeds, P.L.; Chakraborty, S.; Fernandes, C.D.; Charchar, M.J.D.; Ramesh, C.R.; Kexian, Y.; Kelemu, S. Genetic diversity in Colletotrichum gloeosporioides from Stylosanthes spp. at centers of origin and utilization. Phytopathology 2003, 93, 176-185. [CrossRef]

73. Falconí, C.E.; Visser, R.G.; van Heusden, A.W. Phenotypic, molecular, and pathological characterization of Colletotrichum acutatum associated with Andean lupine and tamarillo in the Ecuadorian Andes. Plant Dis. 2013, 97, 819-827. [CrossRef]

74. Correa, G.; Lavalett, L.; Galindo, M.P.; Afanador-Kafuri, L. Uso de métodos multivariantes para la agrupación de aislamientos de Colletotrichum spp. con base en características morfológicas y culturales. Rev. Fac. Nal. Agr. Medellín 2007, 60, 3671-3690.

75. Mena-Rodríguez, E.; Ortega-Cuadros, M.; Merini, L.; Melo-Ríos, A.E.; Tofiño-Rivera, A. Effect of agricultural inputs and essential oils on the soil of vegetables in Colombia's Caribbean region. Corpoica Cienc. Tecnol. Agropecu. 2018, 19, 103-124. [CrossRef]

76. Gamboa-Gaitán, M.Á. Vainillas colombianas y su microbiota. II. Diversidad, cultivo y microorganismos endófitos. Univ. Sci. 2014, 19, 287-300. [CrossRef]

77. Vega, F.E.; Simpkins, A.; Aime, M.C.; Posada, F.; Peterson, S.W.; Rehner, S.A.; Infante, F.; Castillo, A.; Arnold, A.E. Fungal endophyte diversity in coffee plants from Colombia, Hawaii, Mexico and Puerto Rico. Fungal. Ecol. 2010, 3, 122-138. [CrossRef]

78. Villavicencio-Vásquez, M.; Espinoza-Lozano, R.F.; Pérez-Martínez, S.; Sosa del Castillo, D. Hongos endófitos foliares como candidatos a biocontroladores contra Moniliophthora spp. de Theobroma cacao (Malvaceae) en Ecuador. Acta Biol. Colomb. 2018, 23, 235-241. [CrossRef]

79. Manawasinghe, I.S.; Phillips, A.J.L.; Hyde, K.D.; Chethana, K.W.T.; Zhang, W.; Zhao, W.S.; Yan, J.Y.; Li, X. Mycosphere essays 14: Assessing the aggressiveness of plant pathogenic Botryosphaeriaceae. Mycosphere 2016, 7, 883-892. [CrossRef]

80. D'arcy, C.J.; Eastburn, D.M.; Schumann, G.L. Illustrated glossary of plant pathology. In The Plant Health Instructor; The American Phytopathological Society: St. Paul, MN, USA, 2001.

81. Pariaud, B.; Ravigné, V.; Halkett, F.; Goyeau, H.; Carlier, J.; Lannou, C. Aggressiveness and its role in the adaptation of plant pathogens. Plant Pathol. 2009, 58, 409-424. [CrossRef]

82. Agrios, G.N. Plant Pathology, 5th ed.; Academic Press: Burlington, UK, 2005; p. 952.

83. Van Wyk, M.; Heath, R.N.; Tarigan, M.; Vermeulen, M.; Wingfield, M.J. Comparison of procedures to evaluate the pathogenicity of Ceratocystis fimbriata sensu lato isolates from Eucalyptus in South Africa. South. For. 2010, 72, 57-62. [CrossRef]

84. Baroncelli, R.; Amby, D.B.; Zapparata, A.; Sarrocco, S.; Vannacci, G.; Le Floch, G.; Harrison, R.J.; Holub, E.; Sukno, S.; Sreenivasaprasad, S.; et al. Gene family expansions and contractions are associated with host range in plant pathogens of the genus Colletotrichum. BMC Genom. 2016, 17, 555. [CrossRef]

85. Liang, X.; Wang, B.; Dong, Q.; Li, L.; Rollins, J.A.; Zhang, R.; Sun, G. Pathogenic adaptations of Colletotrichum fungi revealed by genome wide gene family evolutionary analyses. PLOS ONE 2018, 13, e0196303. [CrossRef]

86. Russell, P.E. A century of fungicide evolution. J. Agric. Sci. 2005, 143, 11-25. [CrossRef]

87. Carvalho, F.P. Agriculture, pesticides, food security and food safety. Environ. Sci. Policy 2006, 9, 685-692. [CrossRef]

88. De Silva, N.I.; Brooks, S.; Lumyong, S.; Hyde, K. Use of endophytes as biocontrol agents. Fungal. Biol. Rev. 2019, 33, 133-148. [CrossRef]

89. Suárez-Estrella, F.; Arcos-Nievas, M.A.; López, M.J.; Vargas-García, M.C.; Moreno, J. Biological control of plant pathogens by microorganisms isolated from agroindustrial composts. Biol. Control 2013, 67, 509-515. [CrossRef]

90. Urrea, R.; Cabezas, L.; Sierra, R.; Cárdenas, M.; Restrepo, S.; Jiménez, P. Selection of antagonistic bacteria isolated from the Physalis peruviana rhizosphere against Fusarium oxysporum. J. Appl. Microbiol. 2011, 111, 707-716. [CrossRef]

91. Diaz-Herrera, S.; Grossi, C.; Zawoznik, M.; Groppa, M.D. Wheat seeds harbour bacterial endophytes with potential as plant growth promoters and biocontrol agents of Fusarium graminearum. Microbiol. Res. 2016, 186, 37-43. [CrossRef]

92. Kusari, S.; Hertweck, C.; Spiteller, M. Chemical ecology of endophytic fungi: Origins of secondary metabolites. Chem. Biol. 2012, 19, 792-798. [CrossRef]

93. Melo, R.A.; Ariza, P.; Lissbrant, S.; Tofiño, A. Evaluation of agrochemicals and bioinputs for sustainable bean management on the Caribbean coast of Colombia. Agron. Colomb. 2015, 3, 203-211. [CrossRef]

94. Alzate, D.A.; Afanador, L.; Durango, D.L.; García, C.M. Evaluación de la fitotoxicidad y la actividad antifúngica contra Colletotrichum acutatum de los aceites esenciales de tomillo Thymus vulgaris, limoncillo Cymbopogon citratus, y sus componentes mayoritarios. Vitae 2009, 16, 116-125.

95. Albarracín, L.T.; Delgado, W.; Cuca, L.E.; Ávila, M.C. New butyrolactone and other metabolites from the bark of Endlicheria arenosa against of the phytopathogen Colletotrichum tamarilloi. Nat. Prod. Res. 2019, 33, 687-694. [CrossRef]

96. España, M.D.; Arboleda, J.W.; Ribeiro, J.A.; Abdelnur, P.V.; Guzman, J.D. Eucalyptus leaf byproduct inhibits the anthracnosecausing fungus Colletotrichum gloeosporioides. Ind. Crop. Prod. 2017, 108, 793-797. [CrossRef]

97. Martinez, J.; García, C.; Durango, D. Antifungal activity against Colletotrichum acutatum and Colletotrichum gloeosporioides of the major constituents from wood sawdust of Platymiscium gracile Benth. Boletín Latinoam. Caribe Plantas Med. Aromáticas 2017, 161, $14-25$.

98. Pineda, R.; Vizcaíno, S.; García, C.M.; Gil, J.H.; Durango, D. Antifungal activity of extracts, essential oil and constituents from Petroselinum crispum against Colletotrichum acutatum. Rev. Fac. Nac. Agron. Medellín 2018, 71, 8563-8572. [CrossRef] 
99. Osorio, J.; Martínez, E.P.; Hío, J.C. Screening of microbial culture filtrates, plant extracts and fungicides for control of mango anthracnose. Agron. Colomb. 2012, 30, 222-229.

100. Ramírez, S.; Arias, J.D.; Bedoya, J.C.; Rueda, E.A.; Sánchez, C.Y.; Granada, S.D. Metabolites produced by antagonistic microbes inhibit the principal avocado pathogens in vitro. Agron. Colomb. 2015, 33, 58-63. [CrossRef]

101. Pastrana-Camacho, N.; Suárez, Z.; Acosta-González, A.; Arango, C.; Haltli, B.; Correa, H.; Kerr, R.; Duque, C.; Díaz, L.E. Bioprospecting for culturable actinobacteria with antimicrobial properties isolated from rivers in Colombian Orinoquia. Trop. $J$. Pharm. Res. 2016, 15, 1259-1265. [CrossRef]

102. López-Vásquez, J.M.; Angel, M.L.M.; Gutierrez, A.M.L. Factores climáticos y su influencia en la expresión de enfermedades fúngicas en cultivares de Heliconias. Rev. Univ. Sci. 2013, 18, 331-345. [CrossRef]

103. Bolívar, K.; Sanabria, M.E.; Rodríguez, D.; de Camacaro, M.P.; Ulacio, D.; Cumana, L.J.; Crescente, O. Potencial efecto fungicida de extractos vegetales en el desarrollo in vitro del hongo Colletotrichum gloeosporioides (Penz.) Penz. \& Sacc. y de la antracnosis en frutos de mango. Rev. Cient. UDO Agríc. 2009, 91, 175-181.

104. Pineda, J.; Principal, J.; Barrios, C.; Milla, D.; Solano, Y.; Gil, E. In vitro fungistatic property of propolis on three Colletotrichum gloeosporioides isolates. Zootec. Trop. 2010, 281, 83-91.

105. Mochizuki, M.; Yamamoto, S.; Aoki, Y.; Suzuki, S. Isolation and characterisation of Bacillus amyloliquefaciens S13-3 as a biological control agent for anthracnose caused by Colletotrichum gloeosporioides. Biocontrol. Sci. Technol. 2012, 22, 697-709. [CrossRef]

106. Thilagam, R.; Hemalatha, N. Plant growth promotion and chilli anthracnose disease suppression ability of rhizosphere soil actinobacteria. J. Appl. Microbiol. 2019, 126, 1835-1849. [CrossRef] [PubMed]

107. Gholami, M.; Khakvar, R.; AliasgarZad, N. Application of endophytic bacteria for controlling anthracnose disease Colletotrichum lindemuthianum on bean plants. Arch. Phytopathol. Plant Prot. 2013, 46, 1831-1838. [CrossRef]

108. Damasceno, C.L.; Duarte, E.A.; dos Santos, L.B.P.R.; de Oliveira, T.A.S.; de Jesus, F.N.; de Oliveira, L.M.; Góes-Neto, A.; Soares, A.C.F. Postharvest biocontrol of anthracnose in bananas by endophytic and soil rhizosphere bacteria associated with sisal (Agave sisalana) in Brazil. Biol. Control. 2019, 137, 104016. [CrossRef]

109. Manamgoda, D.S.; Udayanga, D.; Cai, L.; Chukeatirote, E.; Hyde, K.D. Endophytic Colletotrichum from tropical grasses with a new species C. endophytica. Fungal Divers. 2013, 61, 107-115. [CrossRef]

110. De Silva, D.D.; Crous, P.W.; Ades, P.K.; Hyde, K.D.; Taylor, P.W. Life styles of Colletotrichum species and implications for plant biosecurity. Fungal Biol. Rev. 2017, 31, 155-168. [CrossRef]

111. Urdaneta, L.; Araujo, D.; Quirós, M.; Rodríguez, D.; Colmenares, C.B.; Poleo, N.; Petit, Y.; Dorado, I. Micobiota endófita asociada a estadios preflorales del guayabo (Psidium guajava L.) y al ácaro plano (Brevipalpus phoenicis) (Geijskes) (Acari: Tenuipalpidae). Rev. Cient. UDO Agríc. 2009, 9, 166-174.

112. Quintero-Mercado, A.; Dangon-Bernier, F.; Páez-Redondo, A. Aislamientos endofíticos de Colletotrichum spp. a partir de hojas y ramas de mango Mangifera indica L. cultivar Azúcar en el municipio de Ciénaga, Magdalena, Colombia. Rev. Acad. Colomb. Cienc. Exact. Fis. Nat. 2019, 43, 65-77. [CrossRef]

113. Rojas, E.I.; Rehner, S.A.; Samuels, G.J.; Van Bael, S.A.; Herre, E.A.; Cannon, P.; Chen, R.; Pang, J.; Wang, R.; Zhang, Y.; et al. Colletotrichum gloeosporioides sl associated with Theobroma cacao and other plants in Panama: Multilocus phylogenies distinguish host-associated pathogens from asymptomatic endophytes. Mycologia 2010, 102, 1318-1338. [CrossRef]

114. Lenné, J.M.; Brown, A.E. Factors influencing the germination of pathogenic and weakly pathogenic isolates of Colletotrichum gloeosporiodes on leaf surfaces of Stylosanthes guianensis. Mycol. Res. 1991, 95, 227-232. [CrossRef] 